\title{
Erkek Evreninde Erkeklik Biçimlerinin Temsili: www.erkekadam.org Üzerine Nitel Bir Analiz
}

Aslı Elgün (Dr. Öğr. Üyesi)

Ege Üniversitesi Illetişim Fakültesi

asli.elgun@ege.edu.tr

Başvuru Tarihi: 02.04.2020

Yayına Kabul Tarihi: 26.05.2020

Yayınlanma Tarihi: 24.07.2020

https://doi.org/10.17680/erciyesiletisim.713519

Öz

Bu çalışma nitel bir yaklaşımla Türkiye'deki "erkek evreni" 'nde erkeklik biçimlerini keșfetmek ve betimlemek üzerine kurgulanmıștır. Çalışmada www.erkekadam.org bloğunda yer alan 188 gönderi tematik analiz yöntemi ile incelenmiştir. İnceleme sonucunda hegemonik erkeklik, madun erkeklik ve eril yaşam tarzı olmak üzere 3 temaya ulaşılmıştır. Hegemonik erkeklik; duygusal olarak güçlü, alfa zihniyeti gösteren, hobileri olan, erkek arkadaşları ile vakit geçiren, kendini düşünen, girișimci, baskın, disiplinli, spor yapan, maskülinitesinin farkında olan olarak tasvir edilmiştir. Madun erkeklik ise duygusal olarak güçsüz, dişil, bezgin, itaatkâr, uysal, disiplinsiz, tek kadın ile yaşamını geçiren erkekler olarak tanımlanmaktadır. Bir başka tema ise erkeğin yaşam biçimine yöneliktir. Gönderiler bir yaşam biçimini ögütlemekte ve erkekler için moda, aksesuar, kozmetik gibi çeşitli konularda reçeteler sunmaktadır.

Anahtar Kelimeler: Erkeklik Çalışmaları, Erkek Evreni, Hegemonik Erkeklik, Madun Erkeklik, Eril Yaşam Tarzı. 


\title{
The Representation of Masculinity Forms in the Manosphere: A Qualitative Analysis on www.erkekadam.org
}

\author{
Aslı Elgün (Asst. Prof. Dr.)
}

iD Ege Üniversitesi University Faculty of Communication asli.elgun@ege.edu.tr

Date Received: 02.04.2020

Date Accepted: 26.05 .2020

Date Published: 24.07.2020

https://doi.org/10.17680/erciyesiletisim.713519

\begin{abstract}
Study aims to describe the forms of masculinity in the manosphere of Turkey using a qualitative approach. Based on the qualitative paradigm, the answers to the questions of how masculinity is represented in a sample taken from the Manosphere were sought. Thematic analysis, a qualitative data analysis method, was used in the study on the basis of the purpose and questions of the study. In the study, 188 posts in the www.erkekadam. org blog are analyzed by thematic analysis method. As a result of the data analysis, three themes are determined: hegemonic masculinity, subordinate masculinity, and masculine lifestyle. Hegemonic masculinity is depicted as an emotionally strong man with an alpha mentality, who has hobbies, who likes spending time with his male friends, is selfthinking, entrepreneurial, dominant, disciplined, sportive, and aware of his masculinity. Subordinate masculinity is defined as an emotionally weak man, who is feminine, weary, obedient, submissive, undisciplined, and spends his life with a single woman. Another theme was about the ideal lifestyles for men. Posts advocate a certain lifestyle and provide life recipes for men on various topics.
\end{abstract}

Keywords: Masculinity Studies, Manosphere, Hegemonic Masculinities, Subordinated Masculinities, Masculine Lifestyles. 


\section{Giriş: Erkeklik Hareketi Üzerine Birkaç Not}

Erkek hareketi, 1970'lerden itibaren Kuzey Amerika'da feminizmden etkilenerek erkekler ve erkeklik üzerine çeşitli yaklaşımlar geliştirmiş bir oluşumdur. Bu hareket içinde farklı ideolojik konumlara sahip gruplar yer almaktadır. I. Dalga erkek hareketi olarak da adlandırılan (Sancar , 2013, s. 28) erkek kurtuluşçuluğu hareketi (men's liberation movement) erkeklerin geleneksel erkeklik rollerini eleştirmek üzerine yoğunlaşmıştır (Carrigan, Connell, \& Lee, 1985). Bu hareketin temsilcileri cinsiyet rollerinin kadınlara olduğu kadar erkeklere de eşit derecede baskıcı olduğunu savunmuşlardır. Kimmel' göre (2013, s. 103-107) 1980'lerden itibaren erkek hareketi "erkek rahatsızlı̆̆ına, mutsuzluğuna neden olan şey nedir?” sorusuna cevap aramaya başlamıştır ve verilen cevaplarla erkek hareketi 3 farklı bakış açısı etrafında değişime uğramıştır. Bunlardan biri feminist ideolojiden yola çıkarak erkekliği sorgulayan (pro)feminist (pro-feminist) bakış açısıdır ve bu yaklaşım zamanla eleștirel erkeklik çalışmalarına dönüşmüştür. Bir diğeri Robert Bly, Micheal Meade, Sam Keen'in aralarında bulunduğu erkekliğin kimlik arayışını yansıtan mitos-inşacı (mythopoetic) görüştür. Son olarak ise "erkeklerin feminizm nedeniyle yitirdiklerini iddia ettikleri hakları hukuk mücadelesi vererek geri almayı hedefleyen" (Bozok, 2009, s. 271) erkek hakları hareketi (men's rights movement) erkek hareketi içinde gelişen kollar olarak görülmektedir. Böylece erkeklerin toplumsal, psikolojik ya da kültürel olarak nasıl inşa edildiğine dair cevaplar aranmaya çalışılmıştır.

Amerika'da erkeklerin kaybolmuş doğalarını yeniden keşfetmesi gerektiği inancı ile ortaya çıkan mitos-inşacı erkeklik hareketi, ritüeller, edebiyat ve mitik anlatılar aracılıyla erkekliği yeniden keşfetmeye çalışmıştır. Robert Bly'ın Iron John adlı eseri hareketin temel eserlerinden biri olarak kabul edilmiştir. Messner'e göre (2000, s. 8) kitabın önemi içeriğinden çok Amerika'da erkeklik konusunu tartışmaya açmasından kaynaklanmaktadır. Bly, eserde geçen yirmi yılda erkeklerin daha düşünceli ve kibar bir hale geldiğini ama bunun onları hala özgürleștirmediğini, onları bu durumun mutlu etmediğini söylemektedir (1990, s. 2-3). Mitos-inşacı hareket özellikle Amerika'daki beyaz, eğitimli, orta-sınıf, orta yaş erkekler tarafından benimsenmiştir (Messner, 2000, s. 18). Amerika'da jeopolitik ve ekonomik açıdan değişiklikler yaşanması, feminist eylemlerin görünürlük kazanarak kültürel ve sosyal değişime neden olması erkeklik krizine neden olmuş ve kültürel, sosyal, ekonomik olarak iktidar kaybettiğini düşünen beyaz, heteroseksüel erkekler bu hareket içinde yer almışlardır (Kimmel \& Kaufman, 1993, s. 17).

Liberal ve radikal feminizmden etkilenen pro-feminist hareket, erkekliği feminizmin ilkelerinden hareketle çözümlemeye çalışmıştır (Green, 2000, s. 402). Liberal profeminist hareket, mevcut siyasi ve ekonomik çerçevede yapılacak olan değişikliklerle toplumsal cinsiyet eşitliğinin sağlanabileceğini savunurken radikal pro-feminist hareket ise kadını ve erkeği baskı altına alan ataerkil yapıyı değiștirmeye odaklanmıștır (Goldrick-Jones, 2004, s. 634). Genel olarak pro-feminist hareket erkeklerin kadınları tahakküm altına aldığı görüşünü benimsemiş ve kadınların toplumda karşılaştıkları eşitsizliğin erkek hegemonyasından kaynaklandığını savunmuştur (Kimmel, 2013, s. 8). Vurgu yaptıkları bir diğer konu ise, iktidar ve erkeklik arasındaki ilișki olmuştur. Hareketi savunanalar kamusal ve özel alanda cinsiyete dayalı iktidarın nasıl oluştuğunun izlerini sürmüşler ve erkeklik ile iktidar arasındaki girift birlikteliğin çözümlenmesi gerektiğini savunmuşlardır (Ashe, 2007, s. 15).

Erkek hakları hareketinin altında yatan temel inanç kadın hareketinin erkekleri yanlış bir şekilde ayrıcalıklı bir sınıf olarak tanımlaması ve kadınların erkeklere göre daha güçsüz 
olduğunu kabul etmesidir (Clatterbaugh, 2013, s. 531). Golberg, Erkek Olmanın Tehlikeleri adlı kitabında erkeğin, cinsel/duygusal/fiziksel güç, iktidar biçimleri, medyadaki temsiller, babalık, aile reisliği, tekeşlilik gibi çeşitli yükler altında ezildiğinden söz etmekte ve feminizmin bunları görmezden geldiğine vurgu yapmaktadır (1994, s. 115-125). Goldberg'e göre güçlü dışsal toplumsal koşullanma içinde olan erkek, kendinin farkında olma yetisini kaybetmiștir ve iyi adam olma uğruna kendini inkar etmekte, düzmece, yapay bir yaşamı devam ettirmektedir (s. 227). Erkekler; yaşadıkları toplumdaki pornografik öğelerden, boşanma ile ilgili hukuksal süreçlerden, şiddet yanlısı olduklarına ilişkin yargılardan, bir ilişki yaşadıklarında yapmak zorunda oldukları ritüellerden etkilenmektedirler ve sadece erkek oldukları için bu durumların kurbanı olmaktadırlar (Messner, 2000, s. 42-44). Erkek hakları hareketi, tüm bu tespitlerini 1980'lerden sonra internetin gündelik yaşamımıza girmesi ile bu siber alana taşımıştır.

\section{Çevrimiçi Topluluklar ve Çevrimiçi Bir Topluluk Biçimi Olarak Erkek Evreni}

Günümüzde tartışılan önemli konuların başında çevrimiçi topluluklar ve bu toplulukların yapısı gelmektedir. Çevrimiçi topluluk kavramı Rheingold (1993) ve Hiltz (1985) tarafından çevrimiçi alanlarda kullanıcılar arasında gözlemledikleri yoğun arkadaşlık, empati ve destek duygularını ifade etmek için kullanılmıştır. Çevrimiçi topluluk, belli bir sanal alan aracılıyla ortak amaç, ilgi etrafında üyelerin bir araya geldikleri, tartışmaya katıldıkları, yorumları ile konuya eşlik ettikleri, işbirliği yaptıkları etkileşimin önemli olduğu gruplar olarak tanımlanmaktadır (Preece \& Maloney-Krichmar, 2005). Çevrimiçi topluluklar, web sayfaları, bloglar, video oyunları, sohbet odaları, sosyal paylaşım siteleri, e-posta listeleri ya da tartışma panoları ile bir araya gelebilmektedirler.

Çevrimiçi toplulukların bazı avantajları ve dezavantajları bulunmaktadır. Çevrimiçi topluluklar kişinin diğer üyelerle fiziksel yakınlık zorunluluğunun olmaması, çeşitliliğe izin vermesi, anonimlik dolayısıyla üyelere eşit şans tanıması, kolay entegrasyona izin vermesi, kişinin kendini rahat ifade edebilmesi, demokratik bir ortam sağlaması açısından avantajlı olarak görülmektedir (Cărtărescu, 2010). Çevrimiçi toplulukların dezavantajları ise cinsiyet, ırk, sosyal sınıf, kültür, dil gibi konularda nefret söylemi, ayrımcılık gibi söylemlerin yeniden üretilmesine imkan tanıması ve üyeler arasında radikalleşmenin önünü açmasıdır (Davidson, Jones, \& Joinson, 2019, s. 2). Grup üyeleri, yığın mesaj gönderme, soru sorma ve soruları yanıtlama, konuşmacı olarak bulunma, trolleme (Turner, Smith, Fisher, \& Welser, 2005); denetleme, aktif üye, pasif üye, teknik uzman, ziyaretçi (Pfeil, Svangstu, Ang, \& Zaphiris, 2011) ya da çaylak, ünlü, gizli, ortalığı alevlendirme, rant sağlayıcı (Golder \& Donath, 2004) rolleri ile bu çevrimiçi topluluklar içinde yer almaktadırlar. Kişilerin gerçek kimlikleri ile çevrimiçi topluluklarda yer alma zorunluluğunun olmaması ise bu alanda bir dezavantaj olarak görülmektedir (Preece \& Maloney-Krichmar, 2005; Sardar, 1995)

Anglosakson dünyada 2000'li yıllardan itibaren "erkek evreni" olarak da adlandırılan erkek hakları savunuculuğu yapan çevrimiçi toplulukların yükselişe geçtiğini görmekteyiz. Son yıllarda gelişen bu söylemin kaynakları ise mitos-inşacı erkek hareketine ve erkek hakları hareketine dayandırılmaktadır. Bu söylem bu hareketlerin çevrimiçi ifadesi, tezahürleri olarak kabul edilmektedir. Kavramın orjinali İngilizce'de erkek anlamına gelen "man" ile alan/küre/sınıf anlamında gelen "sphere" kelimelerinden oluşan "Manosphere" dir. Kavramın güncel olmasından kaynaklanan nedenle ulusal alanyazınında sık kullanımı bulunmamaktadır. Kavram Türkçe alanyazınında Eleștirel Erkeklik İncelemeleri İnisiyatifi tarafından dilimize çevrilmiş olan Messerschmidt'in (2019) kitabında "erkek evreni" 
olarak Türkçe' ye kazandırılmıştır. Bu çeviriden hareketle çalışmada "manosphere"in karşılığı olarak "erkek evreni” kullanılmıștır.

2001 yılında cinsiyet farkları, erkeklik, gündelik yaşamı konu alan "Erkekler Kendi Yollarına Gidiyor"(Men Going Their Own Way) adlı bloğun kurulması, 2007 yılında erkeklere ilişkiler hakkında bilgi veren ve Chateau Heartiste ait bloğun yayına geçmesi, 2009 yılında bu akıma adını veren Manosphere adında bir bir başka bloğun varlığı çevrimiçi ağda erkekler için ilgi topluluklarının başlangıcı olarak kabul edilmektedir (Ging, 2017, s. 2). Bu toplulukların genel özelliği feminizm ve destekçilerine karşı söylemleri taşıyor olmalarıdır (Schmitz \& Kazyak, 2016, s. 2). Erkek evreni erkeklerin ihtiyaçlarının, sıkıntılarının, hayal kırıklıklarının ve arzularının keşfine yönelik websiteleri ya da sosyal medya üzerinden yayın yapan topluluklar olarak kabul edilmektedir (Farrell, Fernandez, Novotny, \& Alani, 2019, s. 87). Bu topluluklar, çocuk velayetinden evsizliğe, iş alanlarından askerlik konusuna kadar erkeklere karşı ayrımcılık deneyimlerini vurgulayan bir erkek hakları aktivizmi söylemini ön plana çıkartmaktadırlar (Schmitz \& Kazyak, 2016, s. 8). Bu evrenin hangi konularla ilgilendiği kadar ilgilendikleri konularla ile ilgili geliștirdikleri dilin ve söylemin niteliği önem arz etmektedir.

Erkek evreninin en önemli özelliği anti-feminist özellik göstermesi ve erkek biçimlerini inşa etmesidir. Bu çevrimiçi topluluklar mizojenist, heteroseksist ve irkçı özellikler göstermektedirler (Ging, 2017, s. 12). Erkek hakları aktivistleri, blog yazarları, cinsellik ve cinsiyetlerarası ilişkiler üzerine uzman olduklarını iddia eden kişiler, erkek evreni için içerik üreten gruplar olarak tanımlanmaktadırlar (Ganesh, 2018, s. 34). Erkek evreninin bir başka özelliği ise içerik üreticilerinin genellikle erkeklerden oluşmasıdır. Bu yüzden bu topluluklar erkek homososyal topluluklar olarak nitelendirilmektedir (Ging, 2017). Homososyallik, aynı cinsten olan kişiler arasındaki cinsel olmayan ilişkilere, etkileşim biçimlerine atıfta bulunmak için kullanılan bir kavramdır (Arrowsmith, 2015, s. viii). Meuser'e göre homososyalitenin fiziksel ve sembolik çağrışımları bulunmaktadır. Fiziksel çağrışım erkek ve kadınların mekânsal ayrılığını imlerken, sembolik çağrıșım ise tutum, değerler sistemi, politik görüşler ile ilgili etkileşimin aynı cinsiyete mensup kişilerle yapılması anlamına gelmektedir ve böylece bu ortamlarda erkek kimliğinin kurulması, sürdürülebilmesi mümkün olmaktadır (Meuser, 2004, s. 396). Bu grupların üretmekte oldukları ve yeni erkeklik olarak adlandırdıkları belli başlı "felsefeleri" ve erkekliğin yeniden inşa edilmesi için savundukları toplumsal normları bulunmaktadır.

Kırmızı Hap öğretisi 1999 yılında gösterime giren Matrix-1 (Wachowski Kardeşler) Filmi'ne gönderimde bulunan ve sembolik anlam ifade eden bir harekettir. Filmin bir sahnesinde Morpheus Neo ile bir konuşma yapar ve insanın doğduğu andan itibaren bir bağımlılık ile doğduğunu, dünyayı özümsemeyen bir hapishanede olduğunu söyler. Morpheus Neo'ya iki şık sunar. Eğer Mavi Hapı seçerse hayat aynen devam edecektir. Kırmızı Hapı alırsa ise gerçek ortaya çıkacaktır (Mcmahon, 2003, s. 193). Bu sembolik bir seçimdir. Gerçeklik, özgürlük Kırmızı Hap ile temsil edilirken Mavi Hap yanılsamayı sembolize etmektedir (Lawler, 2003, s. 165). Bu ikili düşünceden beslenen Kırmızı Hap Hareketi başta Amerika olmak üzere tüm dünyada çevrimiçi alanlarda etkili olmaya başlamıştır. Bu öğreti, modern feminizmi ve feminizmin ortaya koyduğu toplumsal cinsiyet eșitliğini reddetmekte, bunu yerine cinsiyetlerin fiziksel özellikleri nedeniyle doğal rolleri olduğunu öne süren genetik olarak belirleyici bir cinsiyet anlayışına inanan bir felsefeyi savunmaktadır (Ging, 2017; Mountford, 2018). Kırmızı Hap, geleneksel erkekliği ortadan kaldırmak isteyen bir oluşum olarak gördükleri feminizm karşında erkekliği yeniden inşa etmeye çalışan bir topluluktur (Kelly, 2017, s. 69) ve bu erkeklik, kadın düşmanlığı 
felsefesi kullanarak cinsel fetih, sosyal hakimiyet ve kendini geliştirme gibi geleneksel hegemonik amaçlara ulaşmaya yönelik söylemler kurmaktadır (Mountford, 2018, s. 2).

Yeni erkeklik hareketi içinde yer alan bir başka söylem ise Beta ve Alfa erkeklik biçimlerine ilişkindir. Doğada aynı türden olan hayvan grupları içinde baskın olan erkeği tanımlayan Alfa, grubu domine eden ve hiyerarşik olarak en üstte olanı temsil etmektedir (Ging, 2017). Bu bilgiden hareket eden yaklaşım erkekleri de davranışları, rolleri ya da duyuşsal özelliklerine göre kategorize etmekte ve bir hiyerarşi üretmektedir. Messerschmidt bu kategorizasyonu popüler psikolojinin ürettiği bir kavram olarak görmektedir $(2019$, s. 59). Bu popüler yaklaşıma göre Alfa erkekler sosyal statü hiyerarşisinin en tepesinde bulunmaktadırlar. Fiziksel güç, ikna ya da otorite yoluyla Alfa erkekler diğer erkekler ve kadınlar üzerinde tahakküm kurarak bulundukları toplulukta söz sahibi olmaktadırlar. Buna karşın Beta erkekler ise zayıf, itaatkâr olarak nitelendirilmekte ve onların da Alfa erkek olması için öğütler verilmektedir (Kaufman, 2015). Alfa erkek olabilmek için; giyimden beden hallerine kadınlara ve erkeklere karşı davranış biçimlerine kadar her alanda bir dizi ögüt sunulmaktadır (Alexander, 2005, s. 61-64). Bu temsil biçimi kültürde ve toplumda erkeklik biçimlerinin inşasını sağlamaktadır.

Dünyada bu yeni erkeklik söylemini yeniden üreten ve yaygınlaştıran birçok site, blog ya da sosyal medya hesabı bulunmaktadır. Bu site, blog ya da sosyal medya gruplarının temel özelliği Kırmızı Hap Öğretisi ve Alfa/Beta erkeklik biçimleri çerçevesinde söylemler üreterek yeni erkeklik biçimlerini inşa etmesidir. Bu söylemler aynı zamanda kadın düşmanlığı ve şiddet ile ilgili öğeleri de barındırmaktadır.

\section{Erkek Evreni Üzerine Yapılmış Olan Çalışmalar}

Erkek evreni üzerine 2000'li yılların başından itibaren tanımlamaya, betimlemeye ve anlamaya yönelik alayazınında çeşitli çalışmalar bulunmaktadır. Bu çalışmalar genellikle Erkek evreni içinde yer alan bloglar, sosyal medya grupları, anti-feminist özellik gösteren websiteleri üzerindedir.

Farell, Fernandez, Novotny ve Alani (2019) çalışmaları, 2011-2018 arasında bir sosyal haber sitesi olan Reddit'te yer alan 7 alt topluluğun 6 milyon gönderisi üzerinedir. Yazarlar bu alt gruplarda gittikçe artan bir kadın düşmanlığının olduğu ve üyelerin şiddet tutumları sergiledikleri sonucuna varmışlardır.

Van Valkenburgh'un (2018) makalesi Kırmızı Hap Hareketi üzerine yapılan ilk çalışmalardan biridir. Topluluk tarafından oluşturan 26 belgeyi içerik analizi ile inceleyen Valkenburgh, Kırmızı Hap'ın sadece hegemonik erkekliğin bir ifadesi olmadığını, aynı zamanda neoliberal ve bilimsel tartışmaları da barındırdığı sonucuna varmıştır. Ayrıca analiz sonuçlarına göre bu çevrimiçi toplulukta kadınlar birer meta haline getirilmişlerdir.

Ging (2017) çalışmasında, antifeminist erkeklerin kendilerini erkek evreninde söylemsel olarak nasıl kurguladıklarını belirlemeye çalıșmıştır ve bu yeni melez erkekliklerin, çevrimiçi erkek egemenliğini yeniden kurduğu bu süreçte sosyal medyanın teknolojik özelliklerinin etkili olduğu sonucuna varmıştır.

Erkek evreninde yer alan bir site olan The Return of King (Kralın Dönüşü)'i inceleyen Mountford (2018), çalışmada sitede kullanılan başlıkları analiz ederek site içinde kullanılan 13 temel temayı ortaya çıkarmıştır.

Schmitz ve Kazyak (2016) yaptıkları çalışmada 12 erkek hakları aktivistine ait websitesini içerik analizi kullanarak incelemişler ve çağdaş erkek grupları arasında meşruiyet ve 
güç arayışları için sitede yer alan stratejileri ortaya çıkarmaya çalışmışlardır. Çalışmada erkeklik arayışında olan erkekler ile eşitlik arayışında olan sanal kurbanlar olarak iki ideolojik stratejinin varlığını ortaya koymuşlardır.

Massanari'nin (2015) yaptığı çalışması ise Reddit'in yönetişimi, algoritması ve kültürünün toksik teknokültürü nasıl desteklediğine yöneliktir. Massanari, Reddit üzerinde cereyan eden iki olay üzerinde yaptığı analizde paylaşımlarda kadın cinselliğinin aşağılandığı, kadın kullanıcılara yönelik aşağılayıcı söylemlerin oluştuğu ve toksik teknokültürel yapının doğduğu sonucuna ulaşmıştır.

Yapılan çalışmalar göstermektedir ki, erkek evreni içinde yer alan çevrimiçi toplulukların ürettikleri içerik kadın düşmanlığına, hegemonik erkekliğin yeniden inşasına ve biyolojik indirgemeciliğin yeniden üretildiği metinlere dayanmaktadır.

Sinan Akyüz (2010) tarafından yayınlanan Etekli İktidar kitabı Türkiye'de erkek hakları üzerine çıkarılmış olan ilk kitap olarak bilinmektedir. Bu çalışmaya başlarken Türk alanyazınında konunun nasıl ele alındığı ile ilgili bir araștırma yapılmıștır. Türkiye Ulusal Tez Merkezi'nde ve ULAKBİM Dergipark Sistemi'nde "erkek hakları", "erkek evreni", "manosfer" anahtar kelimeleri ile yapilan tarama sonucunda konu ile ilgili herhangi bir çalışmaya rastlanılmamıştır (Aralık, 2019). Bu anlamda çalışmanın Türkiye alanyazınında katkı sağlayacağı düşünülmektedir.

\section{Yöntem}

\section{Araştırmanın Amacı ve Yöntemi}

Erkeklik toplumsal, kültürel ve tarihsel olarak çeşitli aracılar tarafından kurgulanan bir olgudur. Aile, eğitim, kişisel ilişkiler, iş dünyası, askerlik, dil, din erkekliği inşa eden yapılar arasındadır. Erkekliği inşa ve temsil eden ve günümüzde önemi gittikçe artan bir diğer yapı ise internet tabanlı alanlar ve uygulamalardır. Web siteleri, bloglar, sosyal ağ sistemleri bireyin gündelik yaşam pratiklerini yansıttığı ve kültürlendiği öğeler olarak kabul edilmektedir. Ortak amaç, beklenti, ilgi, hedef ya da kaygı ile etkileşimin yoğun olarak yaşandığı bu alanlar yeni toplumsal hareketlerin de görünür olduğu platformlardır.

Bu bilgiler ışığında çalıșma nitel bir yaklaşımla Türkiye'deki erkek evreninde erkeklik biçimlerini keşfetmek ve betimlemek üzerine kurgulanmıştır. Çalışma durum desenine göre tasarlanmış ve nitel araştırma süreçleri çerçevesinde oluşturulmuştur. Nitel araştırma; derinlemesine betimlemeye ve yorumlamaya izin veren, örüntüleri ortaya koymayı amaçlayan, iç içe geçmiş olan değişkenleri analiz etmeye çalışan ve asıl olanın çalışılan durum olduğu bir araştırma yöntemidir (Balcı, 2015, s. 36-37). Nitel paradigmadan hareketle çalışmada erkeklik, erkek evreninin bir parçası olan örneklemde nasıl temsil edilmektedir ve betimlenmektedir sorularına tümevarımsal bir paradigma ile yanıt aranmaya çalışılacaktır. Çalışmada aynı zamanda içerik üreticilerinin gönderi paylaşma sıklıkları konusuna da cevap aranacaktır.

\section{Araştırmanın Örneklemi}

Çalışmada alanyazından hareketle belirlenen "alfa", "alfa erkek", "kırmızı hap", "mavi hap", "maskülinite", "erkek hakları" kelimeleri ile Google arama motoru üzerinden sadece Türkiye'yi kapsayacak bir filtreleme ile arama yapılmıştır. Arama sonucunda belirlenen anahtar kelimelerin gazete haberleri, dergi yazıları, çevrimiçi sözlük gönderileri, çevrimiçi içerik üretilen siteler, flört siteleri, kişisel bloglar, psikolojik danışma merkezlerinin kurumsal websiteleri ve konu ile ilgili içerik üreten blog ve websitelerinde kullanıldığı tespit edilmiştir. Araştırmanın amacı doğrultusunda sadece erkek hakları, kırmızı hap, 
alfa erkeklik ve maskülinite ile ilgili içerik üreten bir site forum(alfaloji.net) ve iki blog (erkekadam.org, erkekgibi.org) sitesine ulaşılmıştır (Aralık 2019). Yapılan inceleme sonucunda erkekadam.org sitesi güncellik, sosyal medya hesaplarının varlığı ve konu çeșitliliği nedenleri ile örneklem olarak tercih edilmiștir.

Blog yayın hayatına 2017 yılında başlamıştır ve halen yayın hayatına devam etmektedir. Mart 2017- Şubat 2020 tarihleri arasında 773 gönderi bloğun içeriğini oluşturmaktadır. Çalışmada Ocak 2019- Aralık 2019 tarihleri arasında yer alan gönderiler örneklem olarak seçilmiştir. Çünkü gönderilerin hiperbağlantıları barındırdığı gözlemlenmiştir ve yakın tarihli gönderileri analiz etmek örneklemin genişlemesi için fırsat olarak görülmüştür. Amaçsal örneklem çerçevesinde bir yılı kapsayan gönderiler ile bu gönderilerde yer alan ve çeşitli tarih aralıklarını içeren hiperbağlantı metinleri analize dahil edilmiştir. Bu ölçütlere göre çalışmada Ocak 2019- Aralık 2019 tarihleri arasında yayınlanmış olan 138 yazı ile çeşitli tarihlerde yayınlanmış olan 50 hiperbağlantı metni olmak üzere 188 gönderi analiz edilmiştir.

\section{Veri Toplama Yöntemi ve Kodlama Süreci}

Çalışmada MAXQDA 2020 (Deneme Sürümü) Nitel Veri Analiz Programı verinin kodlanması ve analizinde kullanılmıştır. Program, nitel çalışmalarda güvenirlik stratejilerinden biri olan analize birden fazla araştırmacının dahil edilmesi konusunda farklı olanaklar sağladığı, ortak çalışmalarda çevrimiçi imkanlara ve değiştirilebilir kod sistem yapısına sahip olduğu için tercih edilmiştir. Programın bir başka özelliği ise büyük veri ile çalışmayı kolaylaştırmasıdır. Bu özelliklerinden dolayı gönderiler ilgili sayfadan kopyalanarak adı geçen programa tarih sırasına göre yüklenmiştir. Bu kopyalama esnasında sayfada yer alan hiperlinkler de göz önüne alınmış ve eğer var ise ilgili tarih belirtilerek o sayfaların da programa girişi sağlanmıştır. Kodlayıcılara kolaylık sağlamak için kod tablosuna araştırma soruları dahilinde iki temel kod (erkek ve erkekliğe ait pozitif nitelendirmeler-erkek ve erkekliğe ait negatif nitelendirmeler) tanımlanmıştır. Ayrıca kodlamalar sırasında erkeklik biçimleri ile ilgili farklı anlam örüntüleri için de "diğer" kısmı belirtilmiştir. Bu temel ayrımdan hareketle de erkeklik biçimlerine ilişkin temalara ulaşılmaya çalışılmıştır.

\section{Araştırmanın Veri Analiz Yöntemi}

Araştırmanın amacı ve soruları çerçevesine dokümanların analizinde bir nitel veri analiz yöntemi olan tematik analiz kullanılmıştır. Tematik analiz, bir çalışmada temaların tespiti için kullanılan nitel bir yöntemdir. Braun ve Clake'e göre (2019, s. 883) tematik analizin aşamaları şu şekildedir: 1. Veriye aşinalık, 2. İlk Kodları oluşturma, 3. Kodların gözden geçirilerek bir araya getirilmesi ve temaların oluşturulması, 4. Temaların kontrolü, 5 . Temaların adlandırılması, 6. Somut, çarpıcı, doğrudan alıntılarla raporlamanın yapılması. Çalışmada da belirtilen süreçler takip edilerek temalara ulaşılmıştır. Çalışmada içerik üreticilerinin gönderi paylaşma sıklıkları nelerdir sorusunun bulgularına ulaşabilmek için ise niceliksel içerik analiz yönteminden faydalanılmıştır.

\section{Geçerlik ve Güvenirlik}

Alanyazınında nitel çalışmalar için önerilen bazı geçerlik ve güvenirlik stratejileri bulunmaktadır. Yıldırım ve Şimşek'e göre uzun süreli etkileşim, ayrıntılı betimleme, amaçlı örnekleme (2013, s. 299) nitel araştırmanın geçerliği için önerilen stratejiler arasında yer almaktadır. Bu stratejiler çerçevesinde çalışmanın raporlama kısmında ayrıntılı betimlemelere yer verilmiş, amaçlı örneklem seçilmiş ve çalışmada yer alan gönderiler iki kodlayıcı tarafından birçok kez gözden geçirilmiştir. Veri iki kodlayıcı 
tarafından MAXQDA Nitel Veri Analizi Programı'nda birbirlerinden ayrı olarak kodlanmış ve ardından bir araya getirilerek karşılaştırma yapılmış, temalar konusunda fikir birliğine varılmıștır.

\section{Bulgular}

Aşağıda araştırma soruları çerçevesinde www.erkekadam.org blog sitesine ait temalar ve içerik üreticilerinin gönderi paylaşma sıklığına ilişkin bulgular yer almaktadır. Temalar altında ise alt temaları oluşturan kodların betimlemelerine yer verilerek konu ayrıntıları ile aktarılmaya çalışılmıştır.

\section{İçerik Üreticilerine İlişkin Bulgular}

Sayfanın temel amaçlarından biri Amerika ve Avrupa'da 2000'li yıllardan sonra görünürlük kazanmıș olan Kımızı Hap Öğretisi, masküliniteyi okuyucularına tanıtmaktır. Sayfanın mottosu "Kımızı Hap, Oyun, Maskülinite ve daha fazlası..." olarak ifade edilmektedir. Sitenin ilk yayına geçtiği Mart 2017 yılı ile çalışmanın yapıldı̆̆ı Şubat 2020 tarihleri arasında sitede yer alan 773 yazının 60 yazar tarafından üretildiği gözlenmiştir. Sitede konuk yazar ismi ile 49 farklı kişi içerik üretmiştir.

Tablo 1: İçerik Üreticilerinin İsimleri ve Yıllara Göre Gönderi Dağılımları

\begin{tabular}{|l|c|c|c|c|c|}
\hline & \multicolumn{3}{|c|}{ Yıllara Göre Gönderi Sayıları } & $\mathbf{2 0 2 0}$ & Toplam \\
\hline Yazar İsimleri & $\mathbf{2 0 1 7}$ & $\mathbf{2 0 1 8}$ & $\mathbf{2 0 1 9}$ & $\mathbf{2 0 2}$ & 551 \\
\hline Mahmut Abi & 214 & 254 & 79 & 4 & 77 \\
\hline Konuk Yazar (49 farklı yazarı kapsamaktadır) & 2 & 45 & 30 & & 39 \\
\hline Sonsuzluk Ve Bir Gün & 6 & 31 & 2 & & 39 \\
\hline Çevirmen Hoca & & 30 & 9 & & 20 \\
\hline Hank Moody & 17 & & 3 & & 16 \\
\hline Dante & & 16 & & & 9 \\
\hline Epavar Man & 1 & 5 & 3 & & 6 \\
\hline Yin & & 4 & 2 & & 6 \\
\hline Mr.Deer & & & 5 & & 5 \\
\hline Centilmen Kulübü & & & 5 & & 4 \\
\hline Göçmen Türk & 4 & & & & \\
\hline Boğaç & & 1 & & & 773 \\
\hline Toplam & 244 & 386 & 138 & & 5 \\
\hline
\end{tabular}

\section{Tematik Analiz ile İlgili Bulgular}

Kodlamalar üç ana kategoriye dayalı olarak gerçekleştirilmiştir: Erkek ve erkekliğe ait pozitif nitelendirmeler, erkek ve erkekliğe ait negatif nitelendirmeler ve diğer. $\mathrm{Bu}$ süreç sonunda pozitif nitelendirmelerin hegemonik erkekliği, negatif betimlemelerin ise madun erkekliği temsil ettiği sonucuna ulaşılmıştır. Diğer kategorisinde ise erkekler için öğütlerin yer aldığı görülmüştür. Bu sonuca göre de aşağıda temalar ve alt temalar kodlanan ifadelerden örneklerle betimlenmeye çalışılmıştır.

\section{Tema 1: Hegemonik Erkekliğe İlişkin Nitelendirmeler ve Betimlemeler}

Yapılan kodlamalar çerçevesinde temalardan biri hegemonik erkekliğe ilişkin nitelendirmeler ve betimlemeler olarak belirlenmiştir. Hegemonik erkeklik, Gramsci tarafından ortaya konmuş olan hegemonya kavramına dayanmaktadır. Hegemonya, toplumsal ve politik kontrolün rızaya dayalı olarak kurulması anlamını taşımaktadır. Connell'ın ortaya attığı hegemonik erkeklikteki hegemonya ise, toplumsal yaşamda 
ve kültürel üretimlerde rizaya dayalı toplumsal üstünlük (Connell, 1998, s. 246) olarak tanımlanmaktadır. Gönderilerde erkeği erkek yapan belli başlı özellikler ve nitelendirmeler sıralanmaktadır. Bu özellikler hegemonik erkeklik biçiminin inşasına yöneliktir.

Erkek Duygusal Olarak Güçlü Olmall: Erkek olmak ile güç arasında girift bir ilişki bulunmaktadır. Fiziksel, toplumsal, cinsel güç özellikle geleneksel toplumlarda erkekliğin bir şartı olarak kabul edilmektedir. Sitede yer alan yazılarda özellikle erkeğin duygusal olarak güçlü olması gerektiği vurgulanmaktadır. "Kadınlar açısından erkeğin DUYGUSAL olarak güçsüz olması onun cazibesini tuzla buz eden bir şeydir. Bunu ÇIRKKIN olmak gibi düşünün. Zayıf ya da güçlü olmak derken DUYGUSAL güçten bahsediyorum. Duygusal güç, fiziksel güçten önemlidir" (Mahmut Abi, 14 Şubat 2019). Bir başka yazar Hank Moody ise yine duygusal gücü bir erkeğin sahip olması gereken en önemli özellik olarak tanımlamaktadır. Yazar "Bak kardeşim, gerçek güç duygusal güçtür. Bunu başarabildikten sonra hayatında başaramayacağın hiçbir şey yoktur" (Hank Moody, 8 Eylül 2017) diyerek okuyucularına seslenmektedir. Duygusal olarak güçlü olan erkek iç ve dış dünyasını, kadınlarla olan ilişkisini daha iyi yönetebilecektir. Siteye göre erkeği duygusal olarak güçsüz kılan erkeklerin yeni toplumsal düzenin kurallarından etkilenmesi ve dişileşmesidir. Günümüz yeni toplumsal düzeni içinde "Erkek "yontulmuştur", bozuktur ve değişime ihtiyacı vardır" (Mahmut Abi , 27 Mart 2017). Sitede duygusal olarak güçlü olan erkek sakin, özgüvenli, sağlam, kontrollü, duygularına hakim olan ve belli etmeyen olarak tanımlanmıştır.

Alfa Zihniyetinde Olmall, Kırmızı Hap Öğretisini Özümsemeli: Alfa; bir erkek grubuna verilen isim değil, zihniyet biçiminin adı olarak betimlenmektedir. Alfa zihniyet doğuştan her erkeğin biyolojik olarak taşıdığı kalıtımsal bir özelliktir. Alfa zihniyet erkeğin bireysel ve savaşçı olması, sakin ve soğukkanlı olması, kendini öncelemesi anlamına gelmektedir. Alfa erkeğin dış görünüșü önemli olmakla birlikte tavır ve halleri onu Alfa yapan daha önemli özellikler olarak nitelendirilmektedir. Örneğin, İngiliz aktör John Statham ya da Steve Mcqueen personaları (Mahmut Abi, 8 Kasım 2017) Alfa erkeklere örnek olarak verilmektedir.

Ancak sadece Alfa zihniyetine sahip olmak yeterli değildir aynı zamanda o Alfa zihniyet hiyerarşisinde de en üst basamaklara tırmanmak temel bir hedef olmalıdır.

"kuralları ihlal eden bir doğal alfa ile karşılaştıklarında, hınç ile dolarlar. Bu tip bir çeliş̧ki karşısında gösterdikleri doğal tepki, alfa terimini kendilerine ve kendi başarılarına en uyan şekilde tanımlayıp, bu adamları dışlamaktır. Ama buradaki asıl çeliş̧i, bu yeniden tanımlanan alfanın, doğal alfa duruşu kadar takdir görmemesidir ki böylece döngü devam eder" (Mahmut Abi, 19 Ekim 2019).

Günümüzde erkeklerin Alfa zihin yapısını yitirmelerinin nedeni olarak da dişileşmiş toplum yapısı gösterilmektedir.

"günümüzde alfa davranış gösterebilecek erkek sayısı, feminen toplum baskısı nedeniyle, olabileceğin çok altında... Bizim gözlemlediğimiz, birçok erkeğin aşırı beta ve feminen zihniyete sahip olması, onların doğasından ziyade feminen beyin ylkamadan kaynaklaniyor... Tek bildiğimiz bugün yı̆̆ınla erkeğin rol modeli eksikliğinden, erkek olan herșeyin ana akım medyada sıklıkla alaya alınmasından ve aşağılanmasından, çok fazla anne etkisi ile yetişmesinden, feminen disney masalları aşkı propogandasından, vs. vs. gerçekte olmaları gerektiğinden çok daha aşağıda oldukları" (Mahmut Abi, 11 Ekim 2017). 
Erkeğin Alfa zihniyete kavuşabilmesi için Kırmızı Hap Öğretisi'ni benimsemesi önemli görülmektedir. Bu bir çeşit erginlemedir ${ }^{1}$. Dişileştirilmiş toplum yapısı içinde doğuştan gelen Alfa özellikler yitirilmiştir ve erkek Beta zihniyete mahkum edilmiştir. Beta zihniyetten Alfa zihniyete geçiş erkeğin önünde zorlu bir yol, aşama olarak görülmektedir. $\mathrm{Bu}$ yolculuk ise Kımızı Hap ile kazanılmaktadır. Kırmızı Hap öğretisi erkeği içinde bulunduğu durumdan kurtarmayı değil, erkeğin hayatını kurtarmayı amaçlamaktadır. Bunun için erkeğin disiplinli, çalışkan ve sabırlı olması gerekmektedir.

"Kırmızı hap ise suratına bir ayna tutuyor, "birader kadınlar sana ve dikkatine değer vermiyor tamam da bunun nedeni senin kendine ve dikkatine değer vermemen olabilir mi" diyor. Bu mesajı kabul etmek ciddi anlamda kişisel sorumluluk ister, sonrasinda harekete geçmek ise disiplin, sabır ve çalışkanlık. Keşke mucize hap olsaydı gençler. Satar milyarder olurdum" (Mahmut Abi, 12 Ocak 2019).

Kırmızı Hap öğretisi ile tanışan erkek "evin reisi ben olmalıyım / ilişki benim çerçevemde olmalı" diyor ama bu öyle hemen olabilecek bir șey değil, erkek sabırlı olmalıdır" (Mahmut Abi, 17 Şubat 2019).

Maskülinitenin Yeniden İnşası: Sitede yer alan yazılar aracılıyla yeniden inşa edilmesi gereken bir maskülinite tanımı yapılmaktadır. Bu maskülinite tanımına göre erkeğin fiziksel özellikleri çok da önem arz etmemektedir. Önemli olan erkeğin kendini tanıması ve testesteron sahibi olmasıdır. "Erkek, damarlarında testosteron dolaşan ve bu testosterondan korkmayan adamdır" (Mahmut Abi, 27 Nisan 2019). Siteye göre maskülinite kadınların arzuladığı bir özelliktir ve Kırmızı Hap Öğretisi'nin temel amacı maskülen benliği geliştirmektir. Kırmızı Hap Öğretisi erkeğin yapması gereken bir dizi eyleme işaret eder. $\mathrm{Bu}$ eylemler sonucunda erkek maskülen nitelik kazanmaktadır. Maskülen olabilmek için,

"Birincisi ve en önemlisi testesteron için ağırlık kaldırmak... Íkincisi, iyi ve sağlıklı beslenin ve iyi uyuyun... Üçüncüsü, eğer çalışmıyorsanız, kendinize bir iş edinin. Eğer b... bir işiniz varsa daha iyisini bulun. Eğer işiniz iyi ise ve siz bir süredir yükselmiyorsanız, işte yükselmenin yollarını arayın" (Mahmut Abi, 12 Aralık 2017).

Bu yeni maskülen tanımında erkek bedeninin spor, sağlıklı beslenme ile inşası ve statü sahibi olabilecek işlerde çalışması önerilmektedir.

Maskülitenin inşa edildiği bir başka öneri ise kadınlarla kurulan empatinin niteliğinde saklıdır. "Amaç empatisiz biri olmak değildir. Amaç duygusal empatinizin sizin üzerinizdeki etkisini azaltmaktır... erkeğin sinirlerinin zayıf olması gibi bir lüksü yok, maskülen olmak istiyorsa elbette" (Konuk Yazar, 25 Kasım 2019). Fiziksel güç, testesteron, sağlıklı, fit bir bedene sahip olma maskülen olmanın bir tarafını oluştururken en önemli bir bașka özellik olarak da duygusal olarak güçlü olma görülmektedir.

Maskülen bir erkek kendi kararlarını vermeli ve kendine odaklanmalıdır.

"Kadın erkek ilişkilerinde maskülen olmanın en büyük ayağı, karar verici olmaktır... Dominant olmak için bir erkeğin kendi kuralları olmalıdır ve kadının kuralları ile oynamamalıdır... Dominant olmak için bir erkeğin bir misyonu olmalıdır ve bu misyonu öncelik yapmalıdır... Öncelikle kendi tatmininize odaklanın, tutkulu olun" (Mahmut Abi, 11 Ekim 2017). 
Sitede yer alan içeriklerden hareketle ideal maskülen erkekliğin bir ölçüsü de esprili olmasıdır. Esprili olma sitede "neg" terimi ile ifade edilmektedir ve bir amacı bulunmaktadır. "Neg” İngilizce "Negative Hit" yani “Negatif Vurma” anlamına gelmektedir. Erkeğin kadına iltifat eder gibi görünmesi ve şaka ile karışık kadının negatif bir özelliğinin şaka ile karıșık vurgulanması yazılarda öğütlenen bir durumdur. "Neg, aşağılama değildir. Neg, ilgisizliği gösteren, çoğu zaman şaka yollu yorumdur" (Çevirmen Hoca, 13 Mayıs 2019). Böylece yapılan espri ile hem kadının ilgisi çekilecek hem de erkeğin kadına karşı ilgisizliğinin altı çizilecektir. Bu tip bir davranışla erkeğin erilliğini göstermesi mümkün olacaktır.

Maskülen erkek tanışır tanışmaz kadın ile hemen bir ilişki düşünmemelidir.

"Bir erkeğin bir kadın ile buluşmaya başladıktan sonra yaptığı en büyük hata, işi hemen ILIŞKIYE itmesidir. Maskülinitesi bastırılmamış bir erkek bu buluşmaları ve seksi ilişkiye çevirmek için kılını kıpırdatmaz. Hatta kadın tarafından gelen ilişki baskılarına da en az birkaç ay direnir" (Mahmut Abi, 12 Ocak 2019).

Erkek Arkadaşlığının Yüceltilmesi: Erkek arkadaşların varlığı, erkek erkeğe sosyalleşme erkekliğin bir diğer göstergesi olarak belirtilmektedir. "Haftada bir kere de olsa erkek arkadaşlarınız ile çıkıp erkek erkeğe yaptığınız aktiviteler olmalı” (Mahmut Abi, 12 Ocak 2019). Yazılarda erkeklerin hemcinsleri ile kurduğu ilişkinin önemli ve gerekli olduğuna dair vurgu yapılmaktadır. Sitede erkek arkadaşlar ile yapılacak aktiviteler de kategorize edilmiştir. "İçinde sizin utanarak yenilme ihtimaliniz olan, tercihen fiziksel aktivite ve doğa içeren aktivitelere ihtiyacınız var" (Mahmut Abi, 9 Ağustos 2019). Böylece içinde rekabet, yenme-yenilme duygusunun yaşandığı bir deneyim paylaşarak eski zamanlarda erkeklerin avlanırken yaşadıkları deneyimlerin edilmesi gerektiği belirtilmektedir.

Erkeğin Cinsel Pazar Değeri: Kadının ve erkeğin aynı paranın ekonomi alanındaki değeri gibi bir pazar değeri bulunmaktadır. "bir kişinin karş̧ı cins gözündeki arzulanabilirlik değeri" (Mahmut Abi, 25 Mayıs 2019) onun pazar değerini belirlemektedir. Bu pazar değerini ise erkeğin ne kadar Alfa ne kadar Beta karaktere sahip olduğu belirlemektedir. Bir başka ifade ile eğer bir erkek Kırmızı Hap Öğretisi'ne uygun davranıyorsa bu pazar değeri yükselecek eğer Mavi Hap Öğretisi'ne uygun davranıyorsa cinsel pazar değeri düșecektir. Gönderilerde erkeğin cinsel pazar değeri tanımlanmıștır. Bu tanımlamaya göre cinsel pazar değerini öncelikle erkeğin duygusal olarak güçlü ve özgüvenli olması belirlemektedir. Ardından ise para ve yakışıklılık bu değeri belirleyen diğer özellikler olarak sıralanmaktadır (Mahmut Abi , 15 Aralık 2019). Bir başka yazısında ise Mahmut Abi rumuzlu yazar erkeğin cinsel pazar değerinin özelliklerini şu şekilde sıralamıștır:

“Erkeklerin CPDsi sadece fiziksel form ve yaş ile değil statü, para ve kişilik ile de belirlendiğinden erkek CPDsi genelde erkeğin hayatına bir yön aradığı ve olgunlaştığı yaşlarda bir plato dönemi geçirdikten sonra 30 yaşından itibaren artarak 36 - 38 yaşında tepe noktasına ulaşlyor. Erkeğin potansiyelini maksimum seviyede gerçekleştirdiğini varsayarsak, bu yaşlar onun aynı zamanda kendine sığınacak uzun süreli bir ilişki / evlilik limanı arayan kadınların gözünde en tepede olduğu nokta" (Mahmut Abi, 25 Mayıs 2019).

Bütün bu betimlemelerin ıșığında erkeğin cinsel değeri yani arzunabilirlik değeri onun maddi ve manevi özelliklerine bağlı olarak inşa edilen bir süreçtir. 


\section{Tema 2: Madun Erkekliğe İlişkin Nitelendirmeler ve Betimlemeler}

Yapılan çalışma çerçevesinde ideal erkekliğe ait özellik ve betimlemelerin karşısına erkeğin aşağıda yer alan temalarda birleştirilmiş olan nitelendirmelerine ve betimlemelerine yer verilmiştir. Bu özellik ve betimlemeler erkeklik ile örtüștürülmeyen ve erkeği ikincil olarak konumlandıran nitelikler olarak betimlenmektedir.

Mavi Hap Yaklaşımını Benimseyen Beta Erkek: Kırmızı Hap Yaklaşımı karşısında Mavi Hap yaklaşımı bulunmaktadır. Mavi Hap yaklaşımı aynı zamanda Beta erkekliğin tanımını da içermektedir. Erkeklik rolleri açısından hiyerarşinin alt tabakasında yer alan Beta erkeği gönderilerde çeşitli açılardan tanımlanmaktadır.

Öncelikle Beta erkeğinin ortaya çıkmasına neden olan "kadın merkezli feminen anlayış ve son 20 yılda erkeklere öğretilen ve feministlerin pozitif ayrımcılık olarak adlandırdıkları bu toplumsal düzendir" (Sonsuzluk ve Bir Gün, 27 Nisan 2019). Bu düzen içinde sosyalleșen erkekler doğuştan gelen Alfa özelliklerini yitirmekte ve değişmektedirler.

Beta erkek, "bir kadının kendisi ile beraber olması için erkek olarak ortaya koyamadığı eksikliklerini, gereğinden fazla ilgi, kaynak ve zaman harcayarak kapamaya çalışan, bunları yapmazsa kadını elde edemeyeceğini veya kaçıracağını sanan adam" olarak tanımlanmaktadır (Mahmut Abi, 9 Ekim 2019). Beta erkek genellikle bir diyet ödeyen ve hayatını istediği gibi yönlendiremeyen kişi olarak tasvir edilmektedir. Literatürde bu durum "beta öder" olarak adlandırılmaktadır. "Beta öder para ve hesapla alakalı bir durum değildir" (Mahmut Abi, 5 Ocak 2019). Daha çok erkeğin feminenleşmesi ile hegemonik erkeklik biçimlerini davranışlarında, fiziksel görünüşünde ve kadınlarla ilişkilerinde gösterememesi anlamında kullanılmaktadır. Böylece Alfa erkeklikle dikotomik bir ilişki tesis edilmektedir. Beta erkeklik "bir grupta kadınları hediyelere ve çiçeklere boğan, istikrarlı efendi çocuklar var. Bunlar kadınlarına iyi kaynaklar sağlayacak kariyerlere sahipler ama erkeksi ve dominant değiller. Bu erkeklere, manosphere'de genelde beta deniliyor" (Mahmut Abi, 5 Mayıs 2017) olarak betimlenmektedir.

Beta erkekler evlilikte de hatalar yapmaktadırlar. Örneğin yaşça kendinden büyük ve çocuklu bir kadınla evlenebilmektedirler. Bu duruma sitede ünlü futbolcu Cesc Fabregas örnek olarak verilmiştir. "Oyun ve kırmızı hap bilgisi olmazsa dünyaca ünlü yakışıklı ve zengin bir futbolcu da olsanız beta öder durumuna düşmekten kurtulamiyorsunuz" (Çevirmen Hoca, 31 Mayıs 2019).

Beta erkeğin küfür ve hakaretle olan ilişkisi de yazılar aracılıyla açıklanmıştır. Küfür ve hakarete başvuran erkek beta kategorisinde görülmektedir. "Bunlar, alfa görünümlü beta hareketleridir ve gerçekten de bu öfke, erkeğin gelişimini olumsuz yönde etkiler. Kadın güdüsel olarak bu tip davranışları olan erkeği, kendinden başka alternatifi olmayan, aciz, kırılgan bir erkek olarak algılar" (Sonsuzluk ve Bir Gün, 27 Nisan 2019).

Mavi Hap zihniyetinde olan Beta erkek utangaç, centilmen ve hayalperesttir. "Mavi haplı çocuk, arkadaşları aracılığı ile bir kızla tanışır. Kızla ilgili düşler kurar. Onun dünyanın en tatlı şeyi olduğunu düşünür... Oğlumuz heyecanlıdır. Tüm utangaç, acayip ve inek yanları ortaya serilir. Ama aynı zamanda ne kadar centilmen olduğunu da kıza gösterir" (Mahmut Abi, 21 Eylül 2017).

Beta erkekle ilgili fiziksel özellikler de tanımlanmıștır: "göbekli, bezgin, gym yolu görmemiş, para kazanmaktan başka artısı olmayan bir erkek olursanız, göreceğiniz standart muamele bu zaten. Ya bekar kalacaksınız ya da size saygısı olmayan bir kadınla beraber olacaksınız" 
(Mahmut Abi, 14 Şubat 2019). Aynı zamanda bu erkeklerin "Hemen hepsi zaten kendi zamanına ve dikkatine değer vermeyen, disiplinsiz, tembel ve zamanlarını boşa harcayan adamlar" (Mahmut Abi, 26 Ocak 2019) olarak görülmektedirler.

Duygusal Adanmışlık Zayıflıktır: Alfa zihniyetinde duygusal olarak güçlü olmak bir erkeği hayatında ne kadar başarılı kılacaksa tam tersi olarak bir erkeğin duygusal olarak güçsüz olması onu yaşamda, iş, aile, kadın ilişkilerinde başarısız kılacak temel ölçüt olarak kabul edilmektedir.

Duygusal olarak güçsüz olmanın çeşitli tanımları bulunmaktadır. Bunlardan biri kadının erkeğin "Ruh İkizi" olduğuna inanmak ve bir kadının peşinden gitmektir. Erkek evreninde bu durum Ruh İkizi Kişilik Bozukluğu (ONEities) olarak tanımlanmaktadır ve "Genelde karşıllıssız sevgi ve odaktaki kişinin tamamen gerçeklikten kopuk bir şekilde idealize edilmesi ile paralel giden hastalıklı romantik saplantı" (Mahmut Abi, 5 Mayıs 2017) olarak tasvir edilmektedir. Beta erkeklerin düştüğü bu durum, onları maskülineteden uzaklaştırmakta ve başarısız bireyler haline getirmektedir.

Kadının duygularına güvenmek ise erkeğin duygusal olarak güçsüzlüğüne vurgu yapan bir diğer durum olarak tanımlanmaktadır. Örneğin, psikolojik olarak yara almış bir ilişkiden yeni çıkan bir kadına güvenmek erkeğin duygusal bir açlık içinde olduğunu göstermektedir.

"Erkekler genelde böyle bir tablo karșisında korumacı ve sahiplenici güdülerine yenilip farkında olmadan Kurtarıcı Șeması'nı takip ederler,... ben o adam gibi pis kaka değilim, sana ihtiyacın olan duyusal yatırımı yapacağım... altmetini taşıyan mesajlar verirler. Kadınlar bu altmetni çok iyi okur ve sizi "beta öder" kategorisine atılabilecek bir erkek olarak değerlendirmeye başlar. Bunun tipik göstergesi ise sizden gittikçe artan dozda duygusal yatırım talep edilmesidir" (Yin, 15 Haziran 2019).

Erkeğin duygusal olarak güçsüz olduğuna dair bir diğer gösterge ise kadınların sorunlarını dinlemesi ve çözüm bulmaya çalışmasıdır. ".... Kızın dert dinleyen pasif merici asla olmayın. Mümkün olduğunca bundan kaçının... Geçmişinde cinsel travma yaşadığını belirten kızlarla iletişimi kesin... Duygusal yükleri ve sorunları sizden fazla olan kadınlarla birlikte olmayın..." (Çevirmen Hoca, 25 Haziran 2019).

\section{Tema 3: Eril Yaşam Tarzı}

Erkeklere sitede çeşitli konularda reçeteler sunulmaktadır. Bu bazen özgün yazıların içeriklerinde bazen ise çeviri yazılar aracılıyla yapılmaktadır. Sitede özellikle gündelik yaşamdan kesitlerin yer aldığı hikayeler aracılıyla konular örneklendirilerek bu bilgilere ve öğütlere yer verilmektedir.

Reçete sunulan konulardan biri evliliktir. "32 yaşından önce evlenmeyin" (Mahmut Abi, 29 Haziran 2019). Evlilik ile ilgili daha kapsamlı ifadeler ise şu şekildedir:

“Aile gazı ile evlenmeyin, Eğer evlenecekseniz, ideal evlilik yaşınıza kadar evlenmeyin, Bilinmeyen ile evlenmeyin, Evlilik konusunda kadını kırmızı alarmlarına dikkat edin. Kadını gözlemleyin ve eğer kırmızı alarmları varsa yol yakınken (imzadan önce bitirin), Bir tanecik oğlumuz evleniyor, hayatta bir kere evleniyorum bahanesi ile musluğu açıp en beta öder erkek benim yarışına girmeyin. Kız ne yaparsa yapsın bunu fazla ödeyerek ödüllendirmeyin" (Mahmut Abi, 27 Aralık 2019).

Yazılar aracılıyla erkeğin boşanma sırasında da nasıl davranması gerektiği anlatılmaktadır. Vaka çalışması başlığı altında yer alan erkeklerin boşanma hikayelerine (Konuk Yazar, 
Haziran 2019; Çevirmen Hoca, Mayıs, 2019; Konuk Yazar, Mayıs, 2019; Mahmut Abi, Nisan, 2019) yazarlar ögütlerle çözüm aramaya çalışmaktadırlar. Ögütlerden biri boşanma sırasında erkeğin özellikle de belli şartlar (cinsel hayatta tatminsizlik, hipergami şüphesi vs.) oluşmuşsa eşinden önce boşanma davasını açmasıdır. "erkeğin bu aşamaya bir kez gelindiğinde yapabileceği tek bir şey var: ön saldırı yani boşanma davasını kadından önce açmak. Hemen bir avukatla görüşmesi zaten şart. Sekssiz evlilik boşanma sebebi ve bunu kullanması lazım" (Mahmut Hoca, 26 Ocak 2019).

Erkeklere sunulan bir başka öneri ise kadın ile kavga sırasında nasıl davranması gerektiğine ilişkindir. "kızgınlık anında kadınla tartışmaya girmek bir erkeğin yapmaması gereken büyük bir hatadır. O kızgınlık anında kadın erkeğin geçmişte yaptıklarını zerre umursamaz / umursayamaz. O an gerçeklik kızgınlıkla tanımlıdır. Bu nedenle de bir erkekle tartışırken ecnebilerin DEER dediği Savun - Açıkla - Mazur Göster - Rasyonelleștir (SAMR), erkeğin yapabileceği en büyük hatadır! Siz bunu nasıl yaparsanız yapın, SAMR boyun eğmek demektir" (Mahmut Abi, 25 Şubat 2019).

Sitede aynı zamanda erkek modası ve yaşam biçimi ile ilgili de öneriler yer almaktadır. Erkek giyimi konusunda üç kurala dikkat etmelidir: Giyimi dikkati yüzüne çekmelidir, erkeğin giydikleri pozitif özelliklerini ön plana çıkartmalıdır ve giyimi maskülen kişiliğini yansıtmalıdır (Konuk Yazar, 23 Aralık 2019). Yazarlara göre erkeğin cilt bakımı önemlidir ve yeme-içmesine dikkat ederek, temiz tutarak, nemlendirerek güneşten koruyarak bunu sağlamalıdır. Sitede bununla ilgili önerilere de çeşitli yıllara ait gönderde yer verilmiştir.

Ayrıca tüm bunlara ek olarak site erkeklere, aldatan kadın karşısında nasıl davranılmalı, dengeli duygusal yatırım nasıl olur, kadın arkadaşlı̆̆ı ne demektir, oyun ile kadın nasıl elde edilir, hipergamiyi yaşayan kadını nasıl anlarsınız, hangi hobileri tercih etmelisiniz gibi çeşitli konularda reçeteler de sunmaktadır.

\section{Sonuç ve Değerlendirme}

$\mathrm{Bu}$ çalışma erkek evreninde erkeklik biçimlerinin nasıl temsil edildiği konusuna odaklanmaktadır. Belli anahtar kelimelerle yapılan Web taraması ve ölçütler bağlamında www.erkeadam.org blog site incelenerek Türkiye'de erkek evreninde erkeklik biçimleri sorgulanmaya, tanımlanmaya ve betimlenmeye çalışılmıştır. Çalışma bir genelleme yapmaktan ziyade Türkiye'de hiç çalışılmamış bir konuya dikkat çekmeyi ve konuyu alanyazınına kazandırmayı amaçlamaktadır.

Bu amaçla çalışmada 188 gönderi MAXQDA 2020 (Deneme Sürümü) Nitel Veri Analiz Programı'nda analiz edilerek tematik sonuçlara ulaşılmıștır. Çalışmada araștırma sorusuna bağlı olarak sadece erkek biçimleri analiz edilmeye çalışılmıştır. Ayrıca sitede yer alan konu etiketlemeleri ve içerik üretici kimlikleri ile ilgili sonuçlar için de adı geçen programda ayrı bir kodlama yapılmıştır.

Mart 2017- Şubat 2020 yılları arasında sitede toplam 773 gönderi yer almıştır. Bu gönderiler ise, 49 tanesi konuk yazar, 11'i daimi yazar olmak üzere 60 kişi tarafından oluşturulmuştur. Sitenin kurucusu olan Mahmut Abi rumuzlu yazar en çok içerik üreten kişi konumundadır. Blogların temel özelliği kişisel sayfa özelliği gösteren günlük niteliğinde olmalarıdır. Bu bağlamda bu blogta yer alan içerik üreten sayısı göz önüne alındığında blog kişisel bir günlük olmaktan öte bir topluluğu temsil eden çevrimiçi bir platform özelliği göstermektedir. Okuyucu yorumlarına açık olması, haberlere yer vermesi, gönderilerin tarihlerinin belirtilmesi bir bloğun yapısal, içeriksel özellikleri ile uyuşurken diğer taraftan yazarların alanyazında belirtildiği gibi rumuz ile blogta yer 
alması erkek evreni özellikleri ile uyum içinde olduğunu bize göstermektedir. Yazarlar anonim kimliklerle bir yandan kendilerini rahatça ifade edebilmekte diğer taraftan da alanyazında eleştirilen noktası ile ifadelerinin sorumluluğundan kaçabilmektedirler.

Çalışmada örneklem içinde yer alan gönderiler öncelikle erkekleri niteleyen pozitif özellikler, erkekleri niteleyen negatif özellikler ve erkeklere ait diğer alanlar olarak kodlanmıştır. Ardından kodlamalar birleştirilerek temalara ulaşılmıştır.

Yapılan kodlamalar çerçevesinde üç ana temaya ulaşılmıştır. Bunlardan biri ideal erkeklik olarak kurgulanan hegemonik erkekliğin inşasına ilişkin söylemleri kapsamaktadır. Hegemonik erkeklik, erkekliğin farklı biçimleri arasındaki ittifak, tahakküm ve itaatkârlığı imlerken içleme, dişlama ve sindirme gibi çeşitli yöntemlerle kurulan cinsiyetler siyasetini açılamak için kullanılan bir kavramdır (Connell, 2019, s. 84). Connell'a göre tek bir erkeklik biçiminden söz edilemez, erkek olmak toplumsal, kültürel ve ekonomik belli süreçleri içermektedir ve her bir erkeklik arasında bu koşullara bağlı olarak oluşan bir hiyerarşik düzen bulunmaktadır. Bu hiyerarşide ideal erkekliği temsil eden hegemonik erkekliktir.

Hegemonik erkeklik erkekadam.org blog sitesinde de çeşitli açlardan tanımlanmakta, betimlenmekte ve inșa edilmektedir. Öncelikle erkeklik bir erginleme sürecinin sonunda elde edilen bir mertebe olarak tanımlanmakta, mitik bir evren inşa edilmeye çalışılmaktadır. Site erkeğin toplumsal olarak iğdiş edildiğine ve dişileştirildiğine vurgu yapmaktadır. Yazarlara göre erkek erkekliğini kadınların egemenliği altına girerek kaybetmiştir. $\mathrm{Bu}$ yüzden de erkekliğini yeniden kazanması gerekmektedir. Bu bir öğrenme sürecidir ve bu süreçte erkek ergin olabilmek için acıyı, korkuyu, kaybetmeyi göze almalıdır. Erginleme sürecinin sonunda "gerçek" erkeklik kazanılacaktır. Bu yeni erkekliğin özelliklerine gelindiğinde yazarlara göre erkek, duygusal olarak güçlü, alfa zihniyeti gösteren, hobileri olan, erkek arkadaşları ile vakit geçiren, kendini öncelemesi gereken (bu önceleme ancak çocuğu varsa değişebilir bir özellik olmalıdır), girişimci, baskın, kadının güvenli limanı olan, disiplinli, spor yapan, maskülinitesinin farkında bir birey olmalıdır. Bu özellikler sitede erkekliğin olmazsa olmaz özellikleri olarak nitelendirilmektedir. Beta erkekten alfa erkeğe geçiş, erkekliği yeniden keşfetme süreci hem içsel bir yolculuğu işaret ederken hem de hegemonik olanı inşa etmektedir.

Gönderi içerikleri günümüzde masküliniteyi yeniden inşa edilmesi gereken bir pozisyon olarak nitelendirmektedir. İçeriklerde, kadınlara iğneleyici şaka yollu ifadeler kullanabilen, baskın, özgüveni yüksek, spor ile uğraşan sağlıklı yaşam ve beslenme kurallarına uyan, yakışıklı, statü sahibi, uzun süreli ilişki yaşamayan, testosteronu yüksek erkekler maskülen erkek olarak betimlenmektedir. $\mathrm{Bu}$ erkeklerin erkek arkadaşları ile olan sosyalleşmeleri ise onanmakta ve dayanışmanın bir gerekliliği olarak gösterilmektedir. Connell'a göre erkekliğin temel faktörlerinden biri de kendi gibi heteroseksüel, hegemonik olanı benimseyen bir gruba dahil olmasıdır (2019, s. 194-197). Blog içeriklerinde de erkekliğin bir sembolü olarak bu durum yüceltilmektedir.

Belirlenen bir başka tema ise madun erkeklik biçimlerine ilişkindir. Madun erkeklik hegemonik erkekliğin karşısındaki özellikleri, nitelikleri, davranış biçimlerini gösteren erkekleri tanımlamak için kullanılmaktadır. $\mathrm{Bu}$ bağlamda madun erkeklik biçimleri hegemonik olanla zıtlık içindedir (Groes-Green, 2009, s. 289). Ortaya çıkan temalara göre erkeklik biçimleri hiyerarşik bir düzeni işaret etmektedir. Alfa zihniyete sahip olan erkek hiyerarşinin en üst mertebesindedir. Fiziksel, duygusal olarak güçlü, espirili, özgüven sahibi, erkek arkadaşları ile sosyalleșen, statü sahibi, cinsel pazar değeri yüksek olan bu 
erkeklik biçimi karşısında güçsüz, bezgin, itaatkâr, uysal disiplinsiz, tek kadın ile yaşamını geçiren Beta erkek zihniyeti hiyerarşik olarak en alt basamaklarda yer almaktadır ve özellikleri itibari ile Alfa zihniyet ile zıtlık göstermektedir. Böylece hegemonik olan karşısında madun bir erkeklik biçimi tanımlanmakta ve bu iki kavram arasında bir derecelendirme yapılmaktadır.

Yapılan çalışma sonucunda ortaya çıkan bir başka tema ise erkeklere sunulan öğütlere ilişkindir. Gönderiler bir yaşam biçimini öğütlemekte ve erkekler için çeşitli konularda reçeteler sunmaktadır. Moda, aksesuar, kozmetik, spor çeşitleri, cilt bakımı, yemeiçme önerileri gönderilerde sıkça işlenen konular arasında yer almıştır. Ayrıca yazarlar tarafından evlilik sırasında, boşanırken, kadınlarla ilişki yaşanırken nasıl davranılması gerektiğine dair erkeklere hap bilgiler, ögütler verilmekte böylece erkekler için bir kalıp çizilmektedir. Bu metinler daha çok 1930'lardan sonra ortaya çıkan erkek magazin dergi içerikleri ile benzerlik göstermektedir. Bir yandan erkeklik rollerini inşa ederken diğer yandan ise erkeği tüketim kültürünün bir parçası haline getirmektedir.

Tüm bu analizler sonucunda erkeklik evreninin bir parçası olan erkekadam.org blog sitesi hegemonik erkekliği yeniden üretirken madun erkeklik biçimini inşa etmekte erkeklere bir yaşam tarzı önermektedir. Bu sonuçlar bu konuda yapılan uluslararası alanyazın çalışmaları ile örtüşmektedir. İçerik üreticileri mitik bir erkekliği ve geleneksel erkeklik biçimlerini yeni bir alanda anonim kimliklerle dile getirmekte, çevrimiçi toplulukların bir parçası olan erkek evreni yeni iletişim olanakları ile görünürlük kazanmakta ve ulusaşırı bir erkeklik temsili sunmaktadır. Durumun yerel, bölgesel ya da küresel hale gelmesi ise bu konu üzerine daha çok çalışma yapılması gerekliliğini doğurmaktadır.

$\mathrm{Bu}$ çalışma erkek evreninin bir parçası olan erkekadam.org blog sitesinde erkeklik biçimleri üzerine şekillenmiştir. Çalışma bir genellemeden ziyade konuyu alanyazınına kazandırmayı, çevrimiçi topluluklarda erkekliklerin görünümlerini tartışmayı hedeflemiştir. Alanyazında benzer bir çalıșmaya rastlanmadığı ve geçerlik, güvenirlik ölçütleri dolayısıyla amaçlı örneklem tercih edildiği için tek bir blog incelemeye dahil edilmiştir. $\mathrm{Bu}$ durum çalışmanın sınırlılığı olarak değerlendirilebilir. Bundan sonra yapılacak olan çalışmalarda bu platformlarda içerik üreten farklı bloglara, sosyal ağ sahipliklerine bakılması önemli gözükmektedir. Ayrıca erkek evrenindeki kadın temsilinin, etkileşimin niteliğinin ve içeriğinin araştırılması, içerik üreticilerle iletişime geçerek çevrimiçi (sosyal ağlar) ve çevrimdışı (gündelik hayat pratikleri) konumlanmalarına bakılması alana katkı sağlayacaktır.

\section{Notlar}

1 Erginleme, "belirli eğitim ve/veya törenlerden sonra toplumun yetişkin öğeleri arasında yer alma" (Strauss, 1994, s. 341) bir statüden/durumdan çeşitli sınavlar, görevler sonucunda diğer bir statüye/duruma geçme anlamına gelmektedir.

\section{Kaynakça}

Akyüz, S. (2010). Etekli İktidar: Erkek Hakları Kitabı. İstanbul: Alfa Yayınları .

Alexander, J. (2005). How to Become an Alpha Male: Attract Women and Become Successful . USA: John Alexander Enterprises.

Arrowsmith, A. (2015). Rethinking Misogyny Men's Perceptions of Female Power in Dating Relationships. England: Ashgate Publishing.

Ashe, F. (2007). The New Politics of Masculinity. New York: Routledge. 
Balcı, A. (2015). Sosyal Bilimlerde Araştırma: Yöntem, Teknik ve İlkeler. Ankara: Pegem Akademi.

Bly, R. (1990). Iron John: A Book About Men. USA: Ingram Publisher.

Bozok, M. (2009). Feminizmin erkekler cephesindeki yankısı: Erkekler ve erkeklik üzerine eleştirel incelemeler. Cogito(58), 270-285.

Braun, V., \& Clarke, V. (2019). Psikolojide tematik analizin kullanımı. Eğitimde Nitel Araștırmalar Dergisi - Journal of Qualitative Research in Education, 873-898. doi:10.14689/issn.2148-2624.1.7c.2s.17m

Carpenter, N. (2014). Yerel ötesi ve topluluk medyası yerel ötesiciliği. B. Yanıkkaya, \& B. Çoban içinde, Kendi Medyanı Yarat (s. 215-253). İstanbul: Kalkedon Yayınları.

Carrigan, T., Connell, B., \& Lee, J. (1985). Toward a new sociology of masculinity. Theory and Society, 14(5), 551-604. doi:https://doi.org/10.1007/BF00160017

Cărtărescu, I. (2010). Utility of online communities - ways one can benefit from one's online life. Journal of Comparative Research in Anthropology and Sociology, 1(2), 7991.

Clatterbaugh, K. (2013). Men's rights movement. M. S. Kimmel, \& A. B. Aronson içinde, Men and Masculinities A Social, Cultural, and Historical Encyclopedia (s. 528-533). USA: ABC-CLIO Publishing.

Connell, R. W. (1998). Toplumsal Cinsiyet ve Íktidar: Toplum, Kişi ve Cinsel Politika. (C. Soydemir, Çev.) İstanbul: Ayrıntı Yayınları.

Connell, R. W. (2019). Erkeklikler. (N. Konukçu, Çev.) Ankara: Phoenix Yayınları.

Çevirmen Hoca. (13 Mayıs 2019). Spontane Neg Örnekleri. Şubat 2020 tarihinde http:// erkekadam.org/2019/05/13/spontane-neg-ornekleri/ adresinden alındı

Çevirmen Hoca. (25 Haziran 2019). Günümüz İlişki Piyasasına Dair Bir Değerlendirme. Şubat 2020 tarihinde www.erkekadam.org. blog sitesi: https://erkekadam. org/2019/06/24/goldmundun-gunumuz-iliski-piyasasina-dair-birdegerlendirmesi/ adresinden alındı

Çevirmen Hoca. (31 Mayıs 2019). Vaka Çalışması: Ben Sana Futbolcu Olamazsın Demedim Betalıktan Kurtulamazsın Dedim. Şubat 2020 tarihinde www.erkekadam.org blog sitesi: http://erkekadam.org/2019/05/31/vaka-calismasi-ben-sana-futbolcuolamazsin-demedim-betaliktan-kurtulamazsin-dedim/ adresinden alındı

Davidson, B. L., Jones, S. L., \& Joinson, A. N. (2019). The evolution of online ideological communities. Plos One, 14(5), 1-25. doi:https:// doi.org/10.1371/journal. pone.0216932.

Delanty, G. (2015). Bir Kavramın Anatomisi Topluluk. (B. Atay, Çev.) İstanbul: Everest Yayınları.

Elam , P. (2014). Mission Statement . Aralık 2019 tarihinde A Voice for Men Web sitesi : https://avoiceformen.com/a-voice-for-men/mission-statement/ adresinden alındı

Farrell, T., Fernandez, M., Novotny, J., \& Alani, H. (2019). Exploring Misogyny across the Manosphere in Reddit. Proceedings of the 10th ACM Conference on Web Science WebSci'19, (s. 87-96). USA. 
Ganesh, B. (2018). The Ungovernability of Digital Hate Culture. Journal of International Affairs, 71(2), 30-49.

Ging, D. (2017). Alphas, Betas, and Incels: Theorizing the Masculinities of the Manosphere. Men and Masculinities, 638-657. doi:10.1177/1097184X17706401.

Goldberg, H. (1994). Erkek Olmanın Tehlikeleri (3. b.). (S. Budak, Çev.) Ankara: Öteki Yayınevi.

Golder, S., \& Donath, J. (2004). Social roles in electronic communities. Internet Research 5.0. London: Emerald Publishing. https://www.researchgate.net/ publication/228794250_Social_roles_in_electronic_communities adresinden alındı

Goldrick-Jones, A. (2004). Profeminist' men. M. S. Kimmel, \& A. B. Aronson içinde, Men and Masculinities A Social, Cultural, and Historical Encyclopedia (s. 634-636). USA: ABCCLIO Publishing.

Green, J. (2000). Profeminist Men's theory. L. Code içinde, Encyclopedia of Feminist Theories (s. 402-403). London: Routledge .

Groes-Green, C. (2009). Hegemonic and Subordinated Masculinities: Class, Violence and Sexual Performance Among Young Mozambican Men. Nordic Journal of African Studies, 286-304.

Hank Moody. (8 Eylül 2017). Duygusal Güç. Şubat 2020 tarihinde www.erkekadam.org blog sitesi: http://erkekadam.org/2017/09/08/duygusal-guc/ adresinden alındı

Hiltz, S. R. (1985). Online Communities: A Case Study of the Office of the Future. Norwood,NJ.: Ablex Publishing.

Kaufman, S. B. (2015, Aralık 10). The Myth of the Alpha Male. Şubat 2020 tarihinde Greater Good Magazine: https://greatergood.berkeley.edu/article/item/the_myth_of_the_ alpha_male adresinden alındı

Kelly, A. (2017). The Alt-Right: Reactionary rehabilitation for white masculinity. Sounding , 66-78.

Kimmel, M. S. (2013). Angry white men: American masculinity at the end of an era. New York : Nation Books .

Kimmel, M. S., \& Kaufman, M. (1993). The New Men's Movement: Retreat and regression with American's Weekend Warriors. Feminist Issues, 13(2), 3-21.

Konuk Yazar. (23 Aralık 2019). Takdir. Şubat 2020 tarihinde www.erkekadam.org blog sitesi: https://erkekadam.org/2019/12/23/takdir/ adresinden alındı

Konuk Yazar. (25 Kasım 2019). Pook'un Kitabı. Şubat 2020 tarihinde www.erkekadam. org blog sitesi: http://erkekadam.org/2019/11/25/pookun-kitabi-15-dersondorduncu-ders/ adresinden alındı

Lawler, J. (2003). Kant Matrix'i Nasıl Yanıltacağımızı Açıklıyor. W. Irvin içinde, Matrix ve Felsefe (M. Sağlam, Çev., s. 161-179). İstanbul: Güncel Yayıncılık.

Mahmut Abi . (15 Aralık 2019). Kırmızı Hap ile Mavi Hap Oyunu Oynamak. Şubat 2020 tarihinde www.erkekadam.org blog sitesi: http://erkekadam.org/2019/12/15/ kirmizi-hap-ile-mavi-hap-oyunu-oynamak/ adresinden alındı 
Mahmut Abi . (27 Mart 2017). Acı Ama Gerçek İğdiş Edilmiş Erkekler Çağı. Şubat 2020 tarihinde www.erkekadam.org blog sitesi: http://erkekadam.org/2017/03/27/ aci-ama-gercek-igdis-edilmis-erkekler-cagi/ adresinden alındı

Mahmut Abi. (1 Mart 2018). Duygusal Güç Bir Erkeğin Sahip Olabileceği En Büyük Güç. Şubat 2020 tarihinde www.erkekadam.org blog sitesi: http://erkekadam. org/2018/03/01/duygusal-guc-bir-erkegin-sahip-olabilecegi-en-buyuk-guc/ adresinden alındı

Mahmut Abi. (11 Ekim 2017). Soru cevap Alfa Erkek ve Beta Erkek Üzerine. Şubat 2020 tarihinde www.erkekadam.org blog sitesi: https://erkekadam.org/2017/10/11/ soru-cevap-alfa-erkek-ve-beta-erkek-uzerine/ adresinden alındı

Mahmut Abi. (12 Aralık 2017). Maskülen Benliği Geliştirmek. Şubat 2020 tarihinde www.erkekadam.org blog sitesi: http://erkekadam.org/2017/12/12/maskulinbenligini-gelistirmek/comment-page-1/ adresinden alındı

Mahmut Abi. (12 Ocak 2019). İlgi Yönetimi. Şubat 2020 tarihinde www.erkekadam.org blog sitesi: http://erkekadam.org/2019/01/12/ilgi-yonetimi-2/ adresinden alındı

Mahmut Abi. (14 Şubat 2019). Kadın Mantığını Anlamak. Şubat 2020 tarihinde www. erkekadam.org blog sitesi: http://erkekadam.org/2019/02/14/kadin-mantiginianlamak/ adresinden alındı

Mahmut Abi. (17 Şubat 2019). Kırmızı Hapın Pratiği. Şubat 2020 tarihinde www. erkekadam.org blog sitesi: http://erkekadam.org/tag/kirmizi-hapin-pratigi/ page/3/ adresinden alındı

Mahmut Abi. (19 Ekim 2019). Alfa. Şubat 2020 tarihinde www.erkekadam.org blog sitesi: http://erkekadam.org/2017/10/19/alfa/ adresinden alındı

Mahmut Abi. (21 Eylül 2017). Bir Erkeğin Kendi Değerini Yükseltmesinin En Kolay Yolu. Şubat 2020 tarihinde www.erkekadam.org blog sitesi: http://erkekadam.org/2017/09/ page/2/ adresinden alındı

Mahmut Abi. (25 Mayıs 2019). Cinsel Pazar Değeri. www.erkekadam.org blog sitesi : http://erkekadam.org/2019/05/25/cinsel-pazar-degeri-nedir/ adresinden alındı

Mahmut Abi. (25 Şubat 2019). Uzun Süreli İlişkide Kadın Erkek Düşünce Şekli. Şubat 2020 tarihinde www.erkekadam.org blog sitesi: https://erkekadam.org/2019/02/25/ uzun-sureli-iliskide-kadin-erkek-dusunce-sekli/ adresinden alındı

Mahmut Abi. (26 Ocak 2019). Aldatan Kadın Belirtileri. Şubat 2020 tarihinde www. erkekadam.org blog sitesi: http://erkekadam.org/2019/01/26/aldatan-kadinbelirtileri/ adresinden alındı

Mahmut Abi. (27 Aralık 2019). Vaka Çalışması Kırmızı Alarmlarla Dolu Bir Evlilik Macerası. Şubat 2020 tarihinde www.erkekadam.org blog sitesi: https://erkekadam. org/2019/12/27/vaka-calismasi-kirmizi-alarmlarla-dolu-bir-evlilik-macerasi/ adresinden alındı

Mahmut Abi. (27 Nisan 2019). ... Sirrı. Şubat 2020 tarihinde www.erkekadam.org blog sitesi: http://erkekadam.org/2019/04/27/picin-sirri/comment-page-2/ adresinden alındı 
Mahmut Abi. (29 Haziran 2019). Bekar Anne Olmak. Şubat 2020 tarihinde www. erkekadam.org blog sitesi: http://erkekadam.org/2019/06/29/bekar-anneolmak/ adresinden alındı

Mahmut Abi. (5 Mayıs 2017). Ruh İkizi Kişilik Bozukluğu. Şubat 2020 tarihinde www. erkekadam.org blog sitesi: http://erkekadam.org/2017/05/05/ruh-ikizi-kisilikbozuklugu/ adresinden alındı

Mahmut Abi. (5 Ocak 2019). Beta Öder. Şubat 2020 tarihinde www.erkekadam.org blog sitesi: https://erkekadam.org/2019/10/09/ilk-bulusma-yemegi/ adresinden alınd

Mahmut Abi. (8 Kasım 2017). Maskülin Erkekler Feminen Kadınları Tercih Ediyorlar. Şubat 2020 tarihinde www.erkekadam.org blog sitesi: http://erkekadam. org/2017/11/08/maskulin-erkekler-feminen-kadinlari-tercih-ediyorlar/ adresinden alındı

Mahmut Abi. (9 Ağustos 2019). Sadece Erkekler Girebilir. Şubat 2020 tarihinde www. erkekadam.org blog sitesi: https://erkekadam.org/2019/08/09/sadece-erkeklergirebilir/ adresinden alındı

Mahmut Abi. (9 Ekim 2019). İl Buluşma Yemeği. Şubat 2020 tarihinde www.erkekadam.org blog sitesi: https://erkekadam.org/2019/10/09/ilk-bulusma-yemegi/ adresinden alındı

Mahmut Hoca. (26 Ocak 2019). Yalvarırım Bana Boşanma Kozu Ver. Şubat 2020 tarihinde www.erkekadam.org blog sitesi: https://erkekadam.org/2019/01/26/yalvaririmbana-bosanma-kozu-ver/ adresinden alındı

Massanari, A. (2015). \#Gamergate and The Fappening: How Reddit's Algorithm, Governance, and Culture Support Toxic Technocultures. New Media and Society, 329-346. doi:10.1177/1461444815608807

Mcmahon, A. (2003). Acı Hapı Yutmak: Matrix'te Varoluşsal Otantiklik ve Bulantı. W. Irvin içinde, Matrix ve Felsefe (M. Sağlam, Çev., s. 190-209). İstanbul : Güncel Yayıncılık .

Messerschmidt, J. W. (2019). Hegemonik Erkeklik: Formülasyon, Yeniden Formülasyon ve Genişleme. (E. E. İnisiyatifi, Çev.) İstanbul: Özyeğin Üniversitesi Yayınları.

Messner, M. A. (2000). Politics of Masculinities, Men in Movements. Lanham: Altamira Press

Meuser, M. (2004). Homosociality. M. S. Kimmel, \& A. Aronson içinde, Men and Masculinities a Social, Cultural, and Historical Encyclopedia (s. 396-398). Santa BArbara, CA: ABCCLIO.

Moore, R., \& Gillette, D. (1995). Kral, Savaşşı, Büyücü, Aşık (Olgun Erkeklik Arketipleri Yeniden Keşfediliyor). (F. Zengin, Çev.) İstanbul: Sistem Yayıncılık.

Mountford, J. B. (2018). Topic Modelling The Red Pill. Social Sciences, 1-16. doi:10.3390/ socsci7030042

Nagle, A. (2016). The New Man of 4Chan. The Baffler, 30, 64-76.

Pfeil, U., Svangstu, K., Ang, C. S., \& Zaphiris, P. (2011). Social Roles in an Online Support Community for Older People. International Journal of Hum. Comput. Interact, 27(4), 323-347. 
Preece, J. (2000). Online Communities: Designing Usability, Supporting Sociability. Industrial Management \& Data Systems, 459-460.

Preece, J., \& Maloney-Krichmar, M. (2005). Online communities: design, theory, and practice. Journal of Computer-Mediated Communication, 10(4). doi:https://doi. org/10.1111/j.1083-6101.2005.tb00264.x

Return of King . (tarih yok). Ocak 2020 tarihinde About: http://www.returnofkings.com/ about adresinden alındı

Rheingold, H. (1993). The Virtual Community: Homesteading on the Electronic Frontier. London: MIT Press.

Sancar, S. (2013). Erkeklik: İmkansız İktidar, Ailede, Piyasada ve Sokakta Erkekler. İstanbul: Metis Yayınları.

Sardar, Z. (1995). alt. civilizations.faq cyberspace as the darker side of the West. Futures, $27,777-794$.

Schmitz, R. M., \& Kazyak, E. (2016). Masculinities in Cyberspace: An Analysis of Portrayals of Manhood in Men's Rights Activist Websites. Social Sciences, 2-16.

Sonsuzluk ve Bir Gün. (27 Nisan 2019). Yanlış Erkek. Şubat 2020 tarihinde www.erkekadam. org blog sitesi: http://erkekadam.org/2019/04/27/yanlis-erkeklik/ adresinden alındı

Strauss, L. C. (1994). Yaban Düşünce. (T. Yücel, Çev.) İstanbul: Yapı Kredi Yayınları.

Turner, T., Smith, M., Fisher, D., \& Welser, H. (2005). Picturing Usenet: Mapping ComputerMediated Collective Action. J. Comput Communication, 1-22.

Van Valkenburgh, S. P. (2018). Digesting the Red Pill: Masculinity and Neoliberalism in the Manosphere. Men and Masculinities, 1-20. doi:https://doi. org/10.1177/1097184X18816118

Wachowski Kardeşler (Yöneten). (1999). Matrix 1 [Sinema Filmi].

Yıldırım, A., \& Şimşek, H. (2013). Sosyal Bilimlerde Nitel Araştırma Yöntemleri. Ankara: Seçkin Yayıncılık.

Yin. (15 Haziran 2019). Rebound Safhası. Şubat 2020 tarihinde www.erkekadam.org blog sitesi: https://erkekadam.org/2019/06/15/rebound-safhasi/ adresinden alındı 


\title{
The Representation of Masculinity Forms in the Manosphere: A Qualitative Analysis on www.erkekadam.org
}

\author{
Aslı Elgün (Asst. Prof. Dr.)
}

\section{Extended Abstract}

Masculinity is a phenomenon constructed socially, culturally and historically by various intermediaries. Family, education, personal relationships, business world, military service, language, and religion are some of the institutions that construct masculinity. Another factor that helps construct and represent masculinity with a gradually increasing importance today is internet platforms and applications. Websites, blogs, and social network systems are considered as platforms where individuals reflect their daily life practices and are cultured. These spaces, where interactions take place often with a shared purpose, expectation, interest, goal or anxiety, are platforms where new social movements become visible. New versions of the Men's Movement are also represented on these platforms.

The websites or social media communities concerned with the discovery of the needs, problems, frustrations, and desires of men are called the Manosphere. These communities highlight a discourse on men's rights activism that emphasizes discriminatory experiences of men, ranging from child custody to homelessness, professional fields, and military service (Schmitz \& Kazyak, 2016, p. 8). These cyberspace blogs, websites, forums, and social media accounts focus on issues related to men>s rights, gender roles, economics, and feminism. The nature of the language and discourse they develop regarding the topics they are interested in this Manosphere are as important as the topics themselves. Studies on the Manosphere (Massanari, 2015; Schmitz \& Kazyak, 2016; Ging, 2017; Mountford, 2017; Valkenburg, 2018; Farell, Fernandez, Novotny \& Alani, 2019) show that these online communities demonstrate misogynist, heterosexist, and racist characteristics and they see masculinity as a structure that needs to be rebuilt.

This study aims to explore and describe the forms of masculinity in the Manosphere of Turkey using a qualitative approach. The study adopts a case study design and incorporates qualitative research processes. Based on the qualitative paradigm, the answers to the questions of how masculinity is represented and described in a sample taken from the Manosphere were sought. The study also aimed to investigate the subject tags, numbers, and percentages of the posts on the website as well as the posting frequencies of content creators.

The study involved a filtered search on Google's search engine that only included Turkey using the keywords "alpha," "alpha male," "red pill," "blue pill," "masculinity," and "men's rights" which were determined based on a literature review. The filtered search showed that the keywords were used in newspaper and magazine articles, online dictionary posts, websites that produce online content, dating sites, personal blogs, corporate websites of psychological counseling centers, and blogs and websites that produce relevant content. In line with the purpose of the study, a forum website that only creates content related to men's rights, red pill, alpha masculinity, and masculinity (alfaloji.net) and two blog websites (www.erkekadam.org, www.erkekgibi.org) were found (December 2019). As a result of the examination, the website Erkekadam.org was chosen as a sample due to its present validity, the existence of related social media accounts, and subject diversity. 
The blog went online in 2017 and is still active. Between 2017-2020, 773 posts were published, which constitute the whole content of the blog. The study selected the posts between January 2019 and December 2019 as samples because the posts contained hyperlinks, and analyzing recent posts was considered an opportunity to expand the sample. Aligned with the purposeful sampling method, the posts published in a year and the hyperlink links included in these posts with a wide range of publishing dates were included in the analysis. According to these criteria, the study analyzed 188 posts, including 143 articles published between January 2019 and December 2019, and 50 hyperlink texts published on various dates.

Thematic analysis, a qualitative data analysis method, was used in the study on the basis of the purpose and questions of the study. The quantitative content analysis method was utilized to find data on the subject tags, numbers and percentages of the posts on the website, and the posting frequencies of content creators. The data were coded separately by two encoders using the MAXQDA Qualitative Data Analysis Program. Then, the results were compared and a consensus was reached on the themes.

As a result of the data analysis, three themes were determined: hegemonic masculinity, subordinate masculinity, and lifestyle prescriptions for men. Hegemonic masculinity was depicted as an emotionally strong man with an alpha mentality, who has hobbies, likes spending time with his boyfriends, is self- thinking, entrepreneurial, dominant, disciplined, sportive, and aware of his masculinity. Subordinate masculinity is defined as an emotionally weak man, who is feminine, weary, obedient, submissive, undisciplined, and spends his life with a single woman. Another theme was about the ideal lifestyles for men. Posts advocate a certain lifestyle and provide life recipes for men on various topics. Men's fashion, accessories, cosmetics, types of sports, skincare, food and drink suggestions are among the sub-themes that are covered in such posts.

The main feature of blogs is that they are diaries that act as a personal page. In this context, due to its high number of content creators, this blog acts as an online platform representing a community. While the posts are open to readers' comments, share the news stories and specify the publishing date complies with the structural and contextual features of a blog page; authors use nicknames to publish posts complies with the features of the Manosphere as stated in the literature. On one hand, the authors can express themselves comfortably using anonymous identities, and on the other hand, they avoid the responsibility of their statements, which was the point criticized in the literature.

As a result of all these analyses, erkekadam.org blog site, which is a part of the Manosphere, proposes a lifestyle to men and constructs a form of subordinate masculinity while reproducing hegemonic masculinity. The results of the study coincide with other studies on this subject in the international literature. Content creators express their ideals of mythical masculinity and traditional forms of masculinity behind anonymous identities on a new platform. The Manosphere, which is a part of online communities, becomes visible with new communication possibilities and offers a transnational representation of masculinity. The fact that this situation has become local, regional, and global brings about the need for more studies on the subject.

Keywords: Masculinity Studies, Manosphere, Hegemonic Masculinities, Subordinated Masculinities, Masculine Lifestyles. 